\title{
58. SUMMARY OF "PROJECT DSDP 42A"
}

\author{
Kenneth J. Hsü, Eidg. Technische Hochschule, Geologisches Institut, Zurich, Switzerland \\ Lucien Montadert, Institute Francais du Petrole, Rueil-Malmaison, France \\ and \\ Robert B. Kidd, Institute of Oceanographic Sciences, Wormley, Surrey, United Kingdom
}

\section{INTRODUCTION}

From the first planning session at Zurich in late September 1972, to our final scientific editing of the manuscripts in August 1976, four years have gone by. The project "DSDP $42 \mathrm{~A}$ " is not only a drilling cruise, but an integrated study on the geologic history of the Mediterranean. There have been a wide assortment of goals, a great number of investigations using vastly different techniques, and we have obtained many results and arrived at some far-reaching conclusions. It is appropriate that an inventory should be taken at the termination of this project. In the subsequent sections we provide a guide to readers of this volume "leading you in" to its various individual chapters.

\section{ORIGIN OF THE MEDITERRANEAN}

One of the major goals of our investigations was to obtain information leading to a new synthesis on the origin of the Mediterranean. We succeeded in sampling oceanic basement in Hole 373A in Tyrrhenian Basin (Site 373 Report). Radiometric dating gave a late Miocene to early Pliocene age for the samples we obtained (Barberi et al; Kreuzer et al; Savelli and Lipparini). Geochemical and petrological studies showed that the basalts are typically oceanic tholeiites (Barberi et al.; Dietrich et al.). Their occurrence in the Tyrrhenian Abyssal Plain is consistent with the postulate that the Tyrrhenian is a Neogene back-arc basin (Barberi et al.). The data are also consistent with a hypothesis that the area of the Tyrrhenian Sea subsided after a former continental crust was broken into a series of crustal slivers, which became septae between dike swarms of oceanic tholeiites (Hsü and Bernoulli). In fact, we wonder whether the difference between the tectonic model of "oceanization" and that of "back-arc spreading" may not be as irreconcilable as the semantic contrast demands (Hsü and Bernoulli).

We did not reach basement at Site 372 on the Menorca margin of the Balearic, but drilled into lower Burdigalian sediments there (Site 372 Report). The analysis of the salinity gradient of its interstitial waters suggests that the basement there might be overlain by a pre-Burdigalian salt deposit (Site 372 Report; McDuff et al.). Drilling evidence combined with seismic data indicates that the rifting phase of the Balearic began in late Oligocene or earliest Miocene (Site 372 Report; Hsü and Bernoulli; Biju-Duval et al.). The basin continued to subside and was more than 1500 me- ters deep before the onset of the Messinian salinity crisis (Wright; Cita et al.).

We failed to reach basement at Site 375 on Florence Rise west of Cyprus. However, the drilled section can be correlated with Cyprus (Baroz et al.). Our knowledge of the geology of Cyprus combined with marine seismic and other data led us to conclude that the Levantine Basin is a relic of the Mesozoic Tethys (Hsü and Bernoulli; Biju-Duval et al.).

The Aegean is the youngest of the Mediterranean basins. Drilling at Site 378 permitted the dating of an episode of Quaternary deformation (Site 378 Report). Paleobathymetric analysis yielded evidence of PlioQuaternary subsidence of the Cretan Basin (Wright).

\section{HISTORY OF MESSINIAN SALINITY CRISIS}

A second major goal of our project was to decipher the history of the Messinian salinity crisis. An overview of the Neogene history indicated that the salinity crisis was the final expression of a succession of events increasingly restricting the Mediterranean (Hsü et al.). Mediterranean was placed on the west side of a supercontinent and its climate became increasingly arid. After a middle Miocene orogeny in the Alps, the link to Paratethys was eliminated (Rögl et al.; Hsü et al.). Cut off from a large supply of fresh water from the Paratethys, the evaporative excess now became serious; only exchange with the Atlantic served to keep the salinity of the Mediterranean Sea moderately normal. The final closure of the straits to the Atlantic took place during early Messinian (Biju-Duval et al.; Cita et al.; Hsü et al.). Deficit in water budget led to an evaporative drawdown of the water level and a partial, or total, desiccation of the isolated Mediterranean (Cita et al.; Hsü et al.).

Tectonic syntheses led to the conclusion that the Mediterranean basins were in existence prior to the onset of the salinity crisis (Hsü and Bernoulli). Seismic evidence confirmed this conclusion (Montadert et al.). Paleobathymetric analyses yielded convincing evidence that the pre-Messinian basins were deep (Benson; Ekdale; Wright; Cita et al.). Petrological and geochemical data also suggested considerable depth of the preMessinian Mediterranean Sea (Bernoulli et al.; Grazzini; Hsü et al.).

The earlier Messinian evaporites are the Main Salt unit, which is present only under Mediterranean abyssal plains and in a few salt basins on land (Montadert et al.). The occurrence of thick halite and potash 
salts required a rather continuous feeding of seawater from the Atlantic. While salts were deposited in deeper basins without drainage outlets, pericontinental basins were the sites of sulfate and carbonate deposition. The separate-basin model, in addition to a "bull's eye" pattern of saline zonation, explains the occurrences of thick monomineralic evaporite deposits; no refluxing of brines need to be postulated (Hsü et al.).

An intra-Messinian closure prevented the continuous influx of seawater and the upper units of the Main Salt of Sicily consisted of recycled salts. The isolation led to further evaporative drawdown, and widespread erosion (Montadert et al.; Hsü et al.). The upper Evaporite of the Messinian had a much wider distribution than the lower Evaporite (Montadert et al.). There may have been repeated flooding and desiccation during the late Messinian which led to cyclic sedimentation (Garrison et al.). Halite and potash salts were also deposited during this time, but their distribution was restricted to the central and the deepest part of the basins (Site 374 Report; Sites 375 and 376 Report; Kuehn and Hsu; Montadert et al.; Hsủ et al.). Isotopic evidence suggests that there was considerable influx of waters from the continents into the desiccated Mediterranean basins (Pierre and Fontes; McKenzie and Ricchiuto; Cita et al.). The water depth was shallow even during stages of submergence, and the salinity was less than normal (Schrader and Gersonde). The occurrence of algal stromatolites indicates a sedimentary environment comparable to the coastal sabkhas of the Persian Gulf (Garrison et al.; Awramik). Palynological studies suggest that the climate had turned cooler and drier since late Tortonian (Bertolani Marchetti and Accorsi). Smectite became a major weathering product under the prevailing conditions (Chamley et al.).

An inundation of the desiccated eastern Mediterranean basins by fresh or brackish waters, probably from Paratethys, led to the appearance of a series of lakes, known collectively as the Lago Mare (Sites 375 and 376 Report; Cita et al.; Hsü et al.). The euryhaline Ammonia becarrii-Cyprides fauna of the Lago Mare is comparable to Paratehtyan faunas (Benson; Cita et al.). The sediments were mainly muds and marls, some of which were diagenetically altered to form dolomite (Bernoulli and Mélières) and a rare mineral luneburgite (Müller et al.). Some of the lakes had a stagnant bottom, where sapropels and sapropelic sediments accumulated (Deroo et al.).

The Messinian Salinity Crisis ended with the opening of the Strait of Gibraltar and with the Pliocene flooding (Cita et al.; Hsu et al.). Paleobathymetric analyses indicate that the Mediterranean again became a deep sea at the beginning of the Pliocene at least as deep as it had been prior to the salinity crisis (Benson; Cita et al.).

\section{PLIOCENE-QUATERNARY HISTORY}

The Pliocene-Quaternary history of the Mediterranean has been well investigated during and after the Leg 13 cruise; it was not the prime goal of the project "DSDP 42A." However, considerable additional information has been acquired. We recognized, for exam- ple, a significant increase in sedimentation rate (Cita et al.) and an increasingly frequent turbidite sedimentation on the Messinian Abyssal Plain (Muller et al.) from the early Pliocene to the late Quaternary. We also found that the age of the Mediterranean sapropels could be extended as far back as the earliest Pliocene (Kidd et al., sapropels) and considerable information was obtained concerning the nature and the genesis of those sapropels (Sigl et al.; Deroo et al.). Changes in the surface and the bottom temperatures of the Mediterranean were deciphered from studies of silicoflagellates and of ostracodes (Benson; Stradner and Bachmann), and climatical changes were defined by palynological analyses (Bertolani Marchetti and Accorsi).

\section{HEAT-FLOW MEASUREMENTS}

Considerable effort was expended in making geothermal measurements. Heat-flow measurements were made at Site 372, 373, 374, 376, and 378 (Erickson and von Herzen). The heat-flow values are higher than normal in the Balearic, Tyrrhenian, and Aegean basins which are of Neogene age. The values are abnormally low in the Ionian and Levantine basins, which are believed to be relics of Tethys.

\section{CORRELATION WITH LAND SECTIONS}

The stratigraphy of the Mediterranean basins as determined by the deep-sea drilling was correlated with that from nearby land sections. The section at Site 372 was compared with western Mediterranean land sequences.(Mauffret et al.; Bizon et al.); the section at Site 374 with those on the Ionian Islands (Fabricius et al.); and the section at Sites 375/376 with those of Cyprus (Baroz et al.). A synthesis of the land geology and the deep-sea drilling information permitted our regional syntheses (Hsü and Bernoulli; Biju-Duval et al.).

\section{OTHER BASIC RESEARCHES}

Finally, we should cite the numerous basic research studies, without which we could not have made our final syntheses. Basic biostratigraphical research includes studies on foraminifers (Cita et al.; Bizon and Glacon; Wright); on nannofossils (Müller); on radiolarians (Sanfilippo et al.); on pteropods (Pastouret); on dinoflagellate cysts (Corradina); on fungii (Franz et al.); and the Pliocene-Quaternary boundary (Bizon and Müller). Basic sedimentological research includes studies on mineralogy and geochemistry (Mélières et al.) and on clay minerals (Chamley et al.); on heavy minerals (Emelyanov et al.); on sapropels (Kidd et al.; Sigl et al.); on diagenesis (McKenzie et al.; Bernoulli and Garrison). Basic geophysical research includes studies of physical properties on all cores (Site Reports) and of paleomagnetism (Hamilton et al.; Petersen et al.).

\section{ACKNOWLEDGMENT}

Project "DSDP 42A" has been an international cooperative venture. The co-chief scientists and the editor would like to thank the many contributors whose diligent work makes this volume possible. 